\title{
PENGKAJIAN BERBAGAI KONSENTRASI RAGI ROTI UNTUK PERTUMBUHAN PLANLET TEBU \\ (Shaccharum spp) var PS 61 IN VITRO
}

\section{Edy setitiWida Utami ${ }^{1}$ ), Dwi Setyo Rini ${ }^{1}$ ), Eka Sugiyarta ${ }^{2}$ )}

1) Jurusan Biologi FMIPA Universitas Air langga Surabaya.

2) Pusat Penelitian Perkebunan Gula Indonesia (P3GI) Pasuruan.

\section{ABSTRACT}

This experiment was expect for the find of alternative substitution of dalapon's herbicide, its have active materials as 2.2 dikhloropropionat acid. The fuction of dikhloropropionat is very important on the differention and growing of sugarcane plantlet.

The purpose of the research was: to know the effect some concentration of Baker's yeast that consists of Saccharomyces cerevisae to growth of sugarcane (Saccharum spp) var PS 61 plantlet.

This experiment was arranged in a Completely Randomized Design with eight treatments and four replications. The treatment were: $(K)$ control; $(P o)$ Without dalapon's herbicide and Baker's yeast; $(0.25 \mathrm{~g} / \mathrm{l})$ medium; Baker's yeast $0.5 \mathrm{~g} / \mathrm{l}$ medium; (PO.75) g/ 1 medium; (P1.0) Baker's yeast $1.0 \mathrm{~g} / 1$ medium; (P1.25) Baker's yeast $1.25 \mathrm{~g} / \mathrm{l}$ medium; (P1.5) Baker's yeast $1.5 \mathrm{~g} /$ medium.

The observation was done by detsruction of the media every two weeks until the twelve weeks to the height of shoots, and length of primary roots.

The results of this experiment showed that the aplication of Baker's yeast media could be increasing the height of shoots and the length of primary roots. Concentration of Baker's yeast that the suitable for growing of the sugarcane plantlet is $0.25 \mathrm{mg} /$.

Key words : Baker's yeast, growth of plantlet, sugarcane, Saccharum spp var PS61, tissue culture. 